\title{
PREVENTING RECRUITMENT TO IMPROVE PROTECTION OF CHILDREN
}

Shelly Whitman and Catherine Baillie Abidi

The Roméo Dallaire Child Soldiers

Initiative

\section{ABSTRACT}

In order to progressively end the recruitment and use of children as soldiers, the world must focus on effective prevention. The impacts of violence on children affected by armed conflict, and particularly those recruited and used as soldiers, are substantial. Thus, in order to break endemic cycles of violence and achieve peace and security globally, we need to prioritize the prevention of recruitment and the protection of children. This article features examples of effective prevention-oriented strategies, including tangible and practical methods that can be implemented towards the ultimate goal of preventing the recruitment and use of children as soldiers.

Keywords: prevention, child soldiers, violence, children and armed conflict, Vancouver Principles 


\section{INTRODUCTION}

Over 420 million children live in areas affected by armed conflict, a fifty percent increase since the 1990s, and many of these children are urgently in need of protection. ${ }^{1}$ The physical, psychological and social impacts of conflict on children are substantial, particularly for those recruited and used as soldiers, and these impacts are heightened by the changing nature of war. ${ }^{2}$ If in the past children were involved in conflict despite their age, they are now being recruited because of their age as a strategic and tactical innovation in contemporary armed conflict. ${ }^{3}$ Today, according to the UN Secretary General's Report on Children and Armed Conflict (2019) $)^{4}$, there are seven national armies and 56 armed groups operating in 14 countries that recruit and use children as soldiers - both boys and girls - and the recruitment and use of children is sustaining violence over generations. ${ }^{5}$ Although many have recognised that children have no place in armed groups, the use of child soldiers persists, especially among non-state armed groups. Thus, in order to break endemic cycles of violence and achieve peace and security globally, the prevention of recruitment and the protection of children needs to be prioritized.

Until recently, efforts to address the recruitment and use of children as soldiers has been reactive - focusing on reintegration and rehabilitation. While this is critical work, responding to both the fatal and non-fatal consequences of violence is a costly exercise, with impacts ranging from health crises, to shattered economies, to the erosion of communities. ${ }^{6,7}$ Breaking the cycle of armed conflict requires more concerted efforts to address the issue preventatively: while it is commonly understood that prevention is better than a cure, preventing violence requires sustained efforts, long-term investment and vision, and a recognition that measuring

1 Save The Children International. (2019). The war on children: Protecting children in the 21st century. London, UK: Save the Children International.

2 United Nations Secretary General. (2019). Report on children and armed conflict. NY: United Nations General Assembly.

3 Conradi, Carl and Whitman, Shelly. "Child Soldiers and Security Sector Reform: A Sierra Leonean Case Study." 2014, June 25. Security Sector Reform Resource Centre. http://www. ssresourcecentre.org/2014/06/25/child-soldiers-and-security-sector-reform-a-sierra-leoneon-case-study/; Tynes, R. (2018). Tools of War, Tools of State. NY: Suny Press.

$4 \quad$ United Nations Secretary General. (2019). Report on children and armed conflict. NY: United Nations General Assembly.

5 Machel, G. (1996). The impact of armed conflict on children. NY: United Nations General Assembly; Shelly Whitman, 'The Responsibility to Protect and Child Soldiers', in Andy Knight and Fraser Egerton (eds.), The Routledge Handbook on the Responsibility to Protect (London: Routledge, 2012).

$6 \quad$ World Health Organization. (2014). Global status report on violence prevention 2014. Geneva: World Health Organization.

7 World Health Organization. (2016). Global plan of action to prevent violence. Geneva: World Health Organization. 
prevention is challenging. ${ }^{8}$ In the long run, prevention is an important investment as it helps to create the conditions for lasting peace.

In order to progressively end the recruitment and use of children as soldiers, the world must focus on effective prevention. A transformational shift is needed to move from good intentions to preventative action. ${ }^{9}$ While prevention is receiving growing attention globally in relation to peace and conflict, such as the emphasis on prevention within the Responsibility to Protect, ${ }^{10}$ the recognition of the links between the recruitment and use of children as soldiers and sustained cycles of violence is under-theorized, under-resourced and under-actioned. ${ }^{11}$ The goal of this article is to highlight the significance of children within the peace and security agenda and to demonstrate how a security sector approach to preventing the use of children as soldiers is essential to disrupt cycles of violence. This article features examples of effective strategies focused on the ultimate goal of preventing the use of children as weapons of war, such as the practical methods highlighted in the Implementation Guidance for the Vancouver Principles on Peacekeeping and the Prevention of the Recruitment and Use of Child Soldiers.

\section{PRIORITIZING PREVENTION}

The visible and invisible impacts of violence against children are extensive, and yet, the World Health Organization argues that violence is a "preventable problem." 12 Preventing violence in the context of children and armed conflict, and particularly in relation to children recruited and used as soldiers, requires explicit attention during times of peace and conflict. ${ }^{13}$ Understanding the risk factors and conditions that lead to armed conflict and the recruitment of children as soldiers, combined with measures to mitigate these risks, can reduce the likelihood of armed conflict and subsequently, violations against children. Despite alarming

$8 \quad$ World Health Organization. (2014). Global status report on violence prevention 2014. Geneva: World Health Organization; Baillie Abidi, C. (2018). Pedagogies for building cultures of peace: Challenging constructions of an enemy. Leiden, The Netherlands: Brill/Sense Publishing.

$9 \quad$ World Health Organization. (2014). Global status report on violence prevention 2014. Geneva: World Health Organization; ICISS, The Responsibility to Protect, December 2001, http://responsibilitytoprotect.org/ICISS\% 20Report.pdf, accessed 10 January 2017; United Nations Report of the Secretary-General: Prevention of armed conflict. A/55/985-S/2001/574 (7 June 2001).

10 ICISS, The Responsibility to Protect, December 2001, http://responsibilitytoprotect.org/ICISS\% 20Report.pdf, accessed 10 January 2017.

11 Dustin Johnson, Shelly Whitman, and Hannah Sparwasser Soroka, "Prevent to Protect: Early Warning, Child Soldiers, and the Case of Syria," Global Responsibility to Protect 10, no. 1-2 (March 22, 2018): 239-59, https://doi.org/10.1163/1875984X-01001012.

12 World Health Organization. (2014). Global status report on violence prevention 2014. Geneva: World Health Organization.

13 International Committee of the Red Cross. 2020. Influencing behavior to prevent human suffering. Geneva: ICRC; World Health Organization. (2014). Global status report on violence prevention 2014. Geneva: World Health Organization. 
trends in relation to the rise of terrorism, the growing impacts of climate change, and the significant decline in global peacefulness over the past decade, the vast majority of global resources are used to intervene and respond after the onset of armed conflict. ${ }^{14}$

The United Nations Security Council argues that "a comprehensive conflict prevention strategy should include, inter alia, early warning, preventive deployment, mediation, peacekeeping, non-proliferation, accountability measures as well as post-conflict peacebuilding, and recognizes that these components are interdependent, complementary, and non-sequential". ${ }^{15}$ The United Nations Security Council Resolution 2427 (2018) further argues for a conflict prevention strategy that "addresses the root causes of armed conflict in a comprehensive manner in order to enhance the protection of children on a long-term basis". ${ }^{16}$ While many community-based, state-driven, and internationally-supported programs have preventative effects, explicit and coordinated programming on conflict prevention, and particularly recruitment prevention, is lacking. ${ }^{17}$

United Nations Security Council Resolution 1612 (2005) identified the recruitment and use of children as soldiers as one of six grave violations against children in armed conflict. ${ }^{18}$ The recruitment of children as soldiers has long-term impacts on communities due to multiple intersecting factors such as the disruption of schooling, the consequences of trauma on development, and the normalization of violence. ${ }^{19}$ The significance of these impacts, and the consequences of recruitment over time, require collaborative and prevention-oriented solutions. Of the six grave violations, the recruitment and use of children can act as a linchpin in conflict prevention efforts: this violation substantially increases a child's risk to be exposed to other grave violations, such as killing and maiming and sexual violence, and at the same time, the prevention of recruitment can significantly reduce overall violations against children that contribute to sustainable peace and development. ${ }^{20}$

14 Institute for Economics \& Peace. (2019). Global Peace Index 2019. Sydney: IEP.

15 United Nations Security Council Statement by the President of the Security Council. S/PRST/2018/1 (18 January 2018).

16 United Nations Security Council Resolution 2427. S/RES/2427 (9 July 2018).

17 United Nations Security Council Statement by the President of the Security Council. S/PRST/2018/1 (18 January 2018); Shelly Whitman, 'The Responsibility to Protect and Child Soldiers', in Andy Knight and Fraser Egerton (eds.), The Routledge Handbook on the Responsibility to Protect (London: Routledge, 2012); ICISS, The Responsibility to Protect, December 2001, http://responsibilitytoprotect.org/ICISS\% 20Report.pdf, accessed 10 January 2017.

18 United Nations Security Council Resolution 1612. S/RES/1612 (26 July 2005).

19 Save The Children International. (2018). The war on children. London, UK: Save the Children International.

20 The 2030 Agenda for Sustainable Development includes a global commitment to end violence against children and acknowledges that eradicating violence is a key component of sustainable development. See: https://www.unicef.org/protection/files/UNICEF_VAC_ToC_2_pager_ 
In order to employ effective prevention strategies, we must understand the wider spectrum of the definition of a child soldier - from the support functions to the frontline roles, to the gendered dynamics, and the contextual realities on the ground. This broader definition includes girls used as human bombs or for sexual purposes, the various support functions and grey areas of association, children born within an armed group, the detention of children, and the indoctrination processes that fuel and set the stage for the involvement of children in armed conflict. ${ }^{21}$ Understanding the nuance around defining who is a child soldier is essential to preventing this grave violation against children. Furthermore, understanding the vulnerability of children to being used by armed groups, criminal networks, gangs, in trafficking and child labour is critical to effectively preventing the recruitment of children. ${ }^{22}$ Equally important is to understand the rationale and motivations that drive armed groups, forces and gangs to use children. How do we mitigate these motivations so as to counter violations against children effectively? This requires an understanding of the arguments and research from all possible angles and perspectives: from the child soldier, to the recruiter, to the community. It also requires an understanding of prevention practices during peace time and during conflict. ${ }^{23}$

What does this mean for early warning and conflict prevention more broadly? Children can be a rallying point for peace: by highlighting violations against children, improving the protection of children through concerted and deliberate actions, and increasing the political will to see children as critical to achieving peace and security, we can set the stage for sustainable peace.

\section{PATHWAYS TO PREVENTION}

The nature of conflict, including the dynamics of how civilians are perceived and treated, has changed dramatically over the past 25 years. Civilians have become increasingly targeted in armed conflict, and a key part of this purposeful targeting has been the clear violation of children's rights, and employment of war tactics that include using children to commit violence as a means to de-stabilize communities. ${ }^{24}$ In response to the increased targeting of civilians, the Responsibility to Protect (R2P) doctrine was created in 2005. At the time, this reflected an evolution in thinking with respect to the protection of human rights and collective

WEB_051217.pdf. Accessed 5 March 2020.

21 Conradi, Carl, Johnson, Dustin, Mc Neil, Jennifer, Reeves, Darin, Whitman, Shelly and Zayed, Tanya. Child Soldiers: A Handbook for Security Sector Actors, (3rd ed.). Halifax, NS: The Roméo Dallaire Child Soldiers Initiative, 2017.

22 Conradi, Carl. "Child Trafficking, Child Soldiering: exploring the relationship between two 'worst forms' of child labour." Third World Quarterly 34:7 (2013): 1209-1226.

23 Op cit, Child Soldiers: A Handbook for Security Sector Actors, (3rd ed.).

24 Whitman, Shelly, "The Responsibility to Protect and Child Soldiers," in The Routledge Handbook on the Responsibility to Protect. Ed. W. Andy Knight and Frazer Egerton: Routledge, London: 2012, p. 152. 
action. ${ }^{25}$ The R2P doctrine entails a clear responsibility to prevent violations against civilians, including children. Supporters of R2P would argue that clarifying the means to operationalize prevention is critical to the entire concept. ${ }^{26}$ As such, understanding how the prevention of the recruitment and use of children as soldiers influences overall conflict prevention is an essential inclusion.

In 2016, parties to the World Humanitarian Summit called for ending grave violations against children as part of "upholding the norms that safeguard humanity." ${ }^{27}$ Yet, children living in conflict zones are among the least likely to be guaranteed these rights. ${ }^{28}$ The drivers of recruitment of children must be addressed systemically in order to prevent it from happening and to ensure that children who have been demobilised do not re-enter armed forces or armed groups. This prevention work must happen at both the macro level (reducing insecurity, conflict resolution, addressing wider issues of inequality, strengthening national protection systems, and so on) and the micro level (strengthening community-based child protection, access to education, intergenerational dialogue, social norm change, parenting skills, psychosocial support, livelihoods, and so forth).

The UN Special Representative of the Secretary-General on Violence Against Children (UNSRSG VAC) argues that ending violence against children is both an ethical and economic imperative. This violence has far-reaching costs on individuals and their families by diverting billions of dollars of social spending from economic development, eroding human and social capital, and severely limiting children from reaching their full potential, which results in huge losses to society as a whole. ${ }^{29}$ Included among the six steps highlighted to end violence against children by the UNSRSG VAC is the need to increase efforts to make violence against children socially unacceptable. Deep-rooted attitudes and behaviours must change with respect to violence against children. This applies to norms around discipline and the use of violence in communities, schools, and families, as well as a need to build upon positive social norms to overcome entrenched beliefs that condone violence against children. ${ }^{30}$

Imperative in this approach to normative change is understanding how children are exposed

25 Cohen, Roberta, "From Sovereign Responsibility to R2P," in The Routledge Handbook on the Responsibility to Protect. Ed. W. Andy Knight and Frazer Egerton: Routledge, London: 2012. P.8.

26 Woocher, Lawrence, "The Responsibility to Prevent," The Routledge Handbook on the Responsibility to Protect. Ed. W. Andy Knight and Frazer Egerton: Routledge, London: 2012. P. 27.

27 UN Secretary General (2016). Annex to the Report of the Secretary-General for the World Humanitarian Summit. Istanbul: United Nations.

28 World Vision International, No Choice: It takes a world to end the recruitment of children 2019.

29 UN SRSG on Violence Against Children, "Six steps to take to end violence against children," https:// violenceagainstchildren.un.org/six_steps_to_end_vac_viewpoint. Accessed 5 March 2020. Ibid. 
to violence, beliefs related to their use in armed conflict, and how these are part of a larger spectrum of overall attitudes and beliefs in a given society. A security sector actor from Sierra Leone who participated in a Roméo Dallaire Child Soldiers Initiative (Dallaire Initiative) training course on preventing the recruitment and use of child soldiers, stated: "Prior to taking your course I did not see the difference between a child working in a market prior to the war and a child being a soldier for an armed group during the war. To me it was just another form of labour for the child. But after taking your course I realised that by engaging the children in violence, we were ruining the future potential of the children and the future of our nation."31 To challenge and change attitudes and beliefs about children and armed conflict, the Dallaire Initiative promotes a Children's Rights Upfront Approach that seeks to elevate children's well-being higher up on the international peace and security agenda, both in terms of making it a priority for all actors, and by ensuring children and youth participate in peace processes that impact their future. The recent release of the Practical Guidance for Mediators to Protect Children in Situations of Armed Conflict by the UN SRSG for Children and Armed Conflict, is an important example of prioritizing the protection of children in peace agreements. ${ }^{32}$

Preventing violence against children in the context of armed conflict requires a dual lens that is focused on prioritizing the protection of children's rights, and understanding the significant operational impacts of the use of children as soldiers. However, these perspectives are largely missing from the international peace and security agenda. The Dallaire Initiative was created in response to this gap, with the intention of bridging sectors to enhance prevention efforts. The Dallaire Initiative focuses on the development and promotion of ways to improve and implement prevention-oriented approaches, by developing standards and clear guidelines to prioritize the safety of children. ${ }^{33}$ This approach includes four main activities that mutually support each other in order to enhance child protection and prevent recruitment:

1. Developing a global network of champions

2. Applying research to practice

3. Influencing policy and doctrine

4. Training and building capacity. ${ }^{34}$

31 Romeo Dallaire Child Soldiers Initiative, Participant Interviews, Freetown Sierra Leone, January 2014.

32 UN SRSG CAAC, "Practical Guidance for Mediators to Protect Children in Situations of Armed Conflict", file:///Users/shellywhitman/Downloads/FINAL-Practical-guidance-for-mediators-to-protect-children-in-situations-of-armed-conflict-003.pdf

33 Whitman, Shelly and Zayed, Tanya. Core Competencies for Security Sector Training on the Prevention of the Use of Child Soldiers. Halifax, NS: The Roméo Dallaire Child Soldiers Initiative, 2016.

34 The Roméo Dallaire Child Soldiers Initiative. Strategic Plan 2019-2021. Halifax, NS: The Roméo Dallaire Child Soldiers Initiative, 2019. 


\section{PREVENTION IN ACTION: THE VANCOUVER PRINCIPLES}

The Vancouver Principles on Peacekeeping and the Prevention of the Recruitment and Use of Child Soldiers ${ }^{35}$ is an example of a collaborative effort to prioritize prevention. The Vancouver Principles, co-created by the Dallaire Initiative and the Canadian Government, are a set of political commitments, now endorsed by over 95 countries, that emphasize proactive and preventative strategies on how to prevent the recruitment and use of children as soldiers. The accompanying Implementation Guidance for the Vancouver Principles ${ }^{36}$ calls for a change in peacekeeping in the methods of operating, of gathering and interpreting intelligence, as well as employing new tactics and strategies - such as scenarios that are practiced and reviewed, lessons learned collected and adapted, and research that is applied to practice. The creation of military doctrine focused on the prevention of the recruitment and use of children, the integration of new training approaches into the curriculum of military staff colleges, and efforts to build champions of change are part of the Vancouver Principles strategy to elevate the protection of children globally and to promote peace.

In the context of the Vancouver Principles, prevention means moving beyond what has been traditionally viewed as child protection training. This does not mean that efforts to bring awareness to child protection have not been, and will not continue to be, important - they set the stage for the initial conversation - but awareness-raising on rights and responsibilities is only the beginning. Preventing violence requires concerted effort to move toward transformational action, where change occurs beyond individuals to permeate institutions, structures and norms. ${ }^{37}$

According to the Implementation Guidance of the Vancouver Principles,

Preventing the recruitment and use of child soldiers is a defining aspect of the Vancouver Principles. Effective preparation of peacekeeping personnel and peacekeeping operations - through all of the elements articulated in the Vancouver Principles - provides for comprehensive prevention. If Member States effectively educate, train, direct, support, and equip their personnel to address the challenges posed by child soldiers, then the strategic and tactical advantage offered by the use of child soldiers can be reduced, and the cycle of child recruitment can be broken. ${ }^{38}$

35 Government of Canada. (2019). Implementation Guidance for the Vancouver Principles. Ottawa: Government of Canada.

36 Government of Canada. (2017). Vancouver Principles on Peacekeeping and the Prevention of the Recruitment and Use of Child Soldiers. Ottawa: Government of Canada.

37 Baillie Abidi, C. (2018). Pedagogies for building cultures of peace: Challenging constructions of an enemy. Leiden, The Netherlands: Brill/Sense Publishing.

38 Government of Canada. (2019). The implementation guidance of the Vancouver Principles, 2019. Ottawa, ON: Government of Canada. https://www.canada.ca/en/department-national-defence/ 
It is important to highlight that the first point of outside contact for many children in armed conflict contexts, including child soldiers, will often be military and police personnel. ${ }^{39}$ Therefore, it is imperative to empower security sector personnel to be able to interrupt the cycle of recruitment and use of children. In order to do so, security sector actors must be prepared for the possibility of confronting child soldiers before they ever face them in active hostilities - otherwise they are forced to juggle ethical considerations against the basic need to protect themselves. ${ }^{40}$ These considerations take time, thought and preparation, which is a luxury most will not have in the context of armed conflict, leaving them unprepared and likely to under- or overreact.

Effective prevention requires equipping security sector personnel:

- for encounters and potential interventions with children in armed conflict;

- to identify and counteract recruitment tactics;

- to recognize and respond to high-risk recruitment areas;

- to support escape by children from armed groups and forces;

- to protect those who have escaped;

- and to understand the gender dynamics of the recruitment and use of children as soldiers.

The Vancouver Principles recognize the interconnected dynamics and respective areas of expertise among those who are involved in peacekeeping missions. It is essential that those best suited to the various functions to protect children are prepared and understand their unique roles and responsibilities: like cogs in a machine, they each need to conduct their functions effectively or the machine breaks down. Strategic complementarity in this context is the exchange of information, sharing of resources and coordination or co-implementation of programmes in order to establish collaboration and achieve an agreed-upon strategic objective; in this case, the prevention of the recruitment and use of children as soldiers. Such an approach creates opportunities for those who would not typically collaborate or communicate in mission areas - such as non-governmental actors, security sector actors, civilian actors, and government actors - to do so, while at the same time building momentum and dialogue towards peace and security.

Implementing effective prevention strategies requires effective planning and preparation. It also requires countries to step up and be leaders in regions that require stability. Critically, it

corporate/reports-publications/vancouver-principles/introduction/prevention.html

39 Child Soldiers: A Handbook for Security Sector Actors, (3rd ed.)

40 Child Soldiers: A Handbook for Security Sector Actors, (3rd ed.) 
means understanding and recognizing the early warning signs of conflict and the role children can play in sustaining or fueling conflict. ${ }^{41}$ The case of Syria, one of the most tragic examples in contemporary conflict where children have been recruited and used as soldiers, is an example of how attention to this particular dynamic of the conflict went unheeded in any coordinated or effective manner. ${ }^{42}$

There are seventeen principles defined in the Vancouver Principles, which collectively elevate the issue of children's rights within peace operations and offer the security sector practical guidance on how to prevent the recruitment and use of children as soldiers. The following section highlights three prevention-oriented strategies, used in three different contexts, to demonstrate practical approaches to applying the Vancouver Principles in order to prevent recruitment and protect children.

\section{PRACTICAL APPLICATION OF THE VANCOUVER PRINCIPLES}

\section{Canadian Armed Forces Doctrine}

In March 2017, the Canadian Armed Forces (CAF) adopted a Joint Doctrine Note on Child Soldiers with the aim to "provide the interim guidance required to address and mitigate the broad challenges posed by the presence of child soldiers in areas where the CAF undertake missions." ${ }^{33}$ Canada began to transform itself from a nation that had an ad hoc policy on engagement with child soldiers to the first NATO member with a doctrinal document on the issue. A key catalyst to this development were the debates on Canadian contributions to peacekeeping in Mali and the potential engagement between CAF members and child soldiers. The Dallaire Initiative's handbook, Child Soldiers: A Handbook for Security Sector Actors, was a critical reference in the drafting of the new doctrine and the Dallaire Initiative played a key role in demonstrating that the adoption of the doctrine could not only enhance the protection of children during armed conflict, but also contribute to the operational success of Canadian Armed Forces missions.

As a result of this joint effort, a number of subsequent and important policy changes took place: it led to Canada endorsing the Safe Schools Declaration, the inclusion of the need for child soldiers training in the 2017 Canadian Department of National Defence Policy Strong, Secure, Engaged, ${ }^{44}$ and in late 2017, the creation of the Vancouver Principles. Today, the CAF

41 Johnson, Dustin, Whitman, Shelly and Sparwasser Soroka. "Prevent to Protect: Early Warning, Child Soldiers, and the Case of Syria." Global Responsibility to Protect. Ed Bellamy, Alex, Davies, Sara, and Glanville, Luke. Brill Nijhoff: Boston. 10:1-2 (2018).

42 Johnson, Whitman, and Sparwasser Soroka, "Prevent to Protect."

43 Government of Canada. (2017). Canadian Forces Joint Doctrine Note: 2017-01 Child Soldiers. Ottawa: Government of Canada. 
are working to understand their current training gaps and how to adapt curriculum and training approaches to implement the Vancouver Principles domestically. The development of doctrine focused on the prevention of the recruitment and use of children was essential to providing the framework for security sector actors to "strategically, tactically, technically and psychologically" 45 prepare for interactions with child soldiers and to prevent child recruitment in the first place.

In July 2019, the Dallaire Centre for Peace and Security was established by the Canadian Government and funded by the Department of National Defence; a watershed moment in establishing the permanence of this collaboration. The newly created Centre has a formal partnership with the Dallaire Initiative to promote the implementation of the Vancouver Principles globally over the next 5 years.

\section{Integrated Approaches in Sierra Leone}

Sierra Leone experienced a brutal civil war in which the world failed to act effectively to prevent many horrific attacks on civilians, and where the recruitment and use of children was pervasive. As children involved in the conflict grew into adults, security sector reform became critical to the future of the country and to achieving sustained peace. ${ }^{46}$

In 2012, the Dallaire Initiative began work with the Republic of Sierra Leone Armed Forces (RSLAF), the Sierra Leone Police Service (SLPS), and the Sierra Leone Correctional Service (SLCS) to develop, pilot and test a holistic approach to preventing the recruitment and use of child soldiers. Initially it required understanding the motivations of the security forces to collaborate, their desire to participate in peacekeeping missions as a credible troop contributing country, and the economic incentives it provided at a time when the UN was exiting Sierra Leone. Cooperation was solidified through the development of Memoranda of Understandings (MoUs) with military, police and correctional sectors. The holistic approach to prioritizing recruitment prevention and child protection involved developing and conducting training with the security sector, including a focus on capacity building through the implementation of integrated curriculum and a Train the Trainer model. ${ }^{47}$ The integration of Dallaire Initiative curriculum within training academies, and the leadership demonstrated by Sierra Leone in relation to preventing the recruitment and use of children as soldiers, offers important insights into the implementation of the Vancouver Principles.

forces.gc.ca/en/canada-defence-policy/docs/canada-defence-policy-report.pdf

45 Government of Canada. (2017). Canadian Forces Joint Doctrine Note: 2017-01 Child Soldiers. Ottawa: Government of Canada.

46 "Child Soldiers and Security Sector Reform: A Sierra Leonean Case Study."

47 Boyter, Josh, Conradi, Carl, Holland, Sam, Whitman, Shelly and Zayed, Tanya. The Romeo Dallaire Child Soldiers Initiative: Sierra Leone Project. Halifax, NS: The Romeo Dallaire Child Soldiers Initiative, 2014. 
Today, Sierra Leone has created policies and practices that aim to ensure children are never again recruited and used as soldiers. The lived experiences of Sierra Leoneans and the research and pedagogical approach of the Dallaire Initiative have combined to create a set of tools and approaches that are now being shared in many different contexts, including in South Sudan and Somalia. ${ }^{48}$ Additionally, several Sierra Leonean Master Trainers have become advocates in nations that currently recruit and use children as soldiers. It is a powerful experience to hear people speaking with conviction about the harmful impacts recruitment and use has for generations to come - having themselves endured conflict and the use of children as soldiers - to nations that are currently in need of ending such abuses.

\section{Rwanda - Centre of Excellence}

Rwanda currently contributes the third-largest number of troops and police to UN missions, ${ }^{49}$ and is geopolitically significant in the Eastern and Central Regions of Africa. Bordered by several nations that have either experienced or are currently experiencing the impacts of the recruitment and use of child soldiers, it has successfully emerged from the horrific genocide of 1994 and has great potential to lead on the African continent on prevention efforts for both genocide and the recruitment and use of child soldiers.

In Rwanda, the Dallaire Initiative is implementing a strategy that includes establishing a Regional Centre of Excellence, which will be a hub for training and research on preventing the recruitment and use of children. This will be led by the Rwanda Defence Force's (RDF) own example to adopt prevention-oriented doctrine, integrate training throughout their rank structures, ensure every peacekeeping battalion is adequately trained on the prevention of recruitment and child protection, and include an evaluation by the Dallaire Initiative in their annual lesson learned exercises. These actions demonstrate how the Vancouver Principles can be implemented holistically and systematically. As the first African nation to endorse the Vancouver Principles, Rwanda continues to lead with a Children's Rights Upfront approach.

The Rwandan Centre of Excellence, along with the Dallaire Centre of Excellence on Peace and Security, will enable the global community to coordinate on research, policy and practice to elevate children as a priority within peace operations and peace processes.

\section{CONCLUSION}

Effective prevention requires states to take responsibility for the rights of children and to create conditions that prevent the recruitment and use of children as soldiers. For every country that

48 Gbow, Musa, Johnson, Dustin, Reeves, Darin and Whitman, Shelly. Child Protection Capacity Building in Somalia. Halifax, NS: The Romeo Dallaire Child Soldiers Initiative, 2013. 
fails to effectively train their forces, they leave the window wide open for those who wish to exploit children. States who are joining the global effort to prevent this grave violation have an opportunity to lead on the global implementation of the Vancouver Principles, as an important strategy towards recruitment prevention and child protection.

Our failure to reduce the involvement of children in armed conflict today will only create more leaders that have been educated in violence for tomorrow. As such, effective prevention must be a priority for the global peace and security agenda. We must see conflict through the lens of the children who are impacted and used to perpetrate violence, as this is critical to breaking endemic cycles of violence and generational warfare.

Dr. Shelly Whitman is the Executive Director of the Roméo Dallaire Child Soldiers Initiative, based at Dalhousie University in Halifax, Canada. Dr. Catherine Baillie Abidi is the Director of Research \& Learning at the Roméo Dallaire Child Soldiers Initiative. 